\title{
Resettlement demands
}

\section{Moscow}

TENS of thousands of people carried banners through the streets of Minsk, the capital city of Byelorussia, on 30 September to protest against delays and misinformation over the clean-up of contamination from the Chernobyl nuclear reactor explosion of April 1986. Although city authorities did not give official approval, the three-hour rally, attended by seven people's deputies of the USSR (members of parliament), went smoothly.

Ivan Lishtvan, vice-president of the Byelorussian Academy of Sciences, told the crowd that in Byelorussia, the republic worst affected by the Chernobyl disaster, the "optimistic forecasts" of the AllUnion Committee for Radiation Defence, which has been directing the official cleanup, have proved "fallacious". He said that although the number of people affected by various illnesses is still growing, and although little is known about the effects of low-levels of radiation, the USSR Ministry of Health insists that people can live in contaminated areas.

"They want to make people live where they shouldn't", Lishtvan said, declaring that in the opinion of the Byelorussian Academy, people living in affected areas should be resettled without delay. The concerns of the academy have been echoed by the local population, which wants the federal clean-up programme in Byelorussia to heed the Academy's advice. In a few weeks, a new plan will be brought

\section{SCIENCE IN SCHOOLS}

\section{No more creationism}

\section{San Francisco}

THE state of California, which accounts for about 11 per cent of the US school textbook market, has given publishers a broad hint about the wares they should be offering. Last week, its influential Curriculum Commission voted overwhelmingly to give evolution a central place in its science framework, and to relegate creation theory to a religious setting. After a public hearing on 25 October, the state Board of Education is expected to vote on the framework in November. Textbook guidelines are revised every seven years in California, and the new recommendations will take effect in 1992. California is closely watched by publishers, who economize by producing standardized textbooks.

"Creation science is not a science and has no place in the science curriculum", said Curriculum Commission chairman Dan Chernow, a former member of the Board of Education. Creationism, he added, should be discussed along with other religious issues - either in the history and social science curriculum or the English and language arts curriculum. Robert Buderi before the Byelorussian Supreme Soviet. Academician Yevgeni Velikhov, a vicepresident of the All-Union academy as well as director of the Kurchatov Institut and a people's deputy of the USSR, spoke at the rally to declare the support of the Union Academy of Sciences for the Byelorussian view.

Although there is now a policy of distributing personal dosimeters to the populace, the technical problem of making enough has yet to be addressed.

Some 1,500 dosimeters will have been produced by the end of the year, Velikhow reported, and over 100,000 in 1990 . But this may not be enough to give a dosimeter to everyone who wants one, given that few people in Byelorussia are prepared to accept official statements on the extent of contamination.

Stanislav Shushkevich, pro-rector of the Byelorussian University and also a people's deputy, complained that from the outset there had been little truthful information. A demand was made for criminal charges, for misuse of office, to be laid against certain former and current officials said to be responsible for the atmosphere of secrecy around the Chernobyl explosion and its aftermath. "This will be done, sooner or later. There is no escaping an ecological Nuremberg", said author and people's deputy Ales Adamovich, who charged that because the magnitude of the disaster had been kept concealed, Byelorussia had been allocated insufficient federal money for the clean-up. And some of those resources that had been allocated were wasted, for example in the construction of new villages which will have to be evacuated anyway.

The relief fund for the affected areas of Byelorussia is now getting numerous donations, but is is not clear who will control the money, and how it will be distributed. Izvestia has recently reported that 542 million roubles from the federal charity fund, donated shortly after the Chernobyl explosion, was used to cover state expenses at the power station. To avoid similar misuses, speakers at the rally agreed that people's deputies for the affected areas of Byelorussia should have control of the donated funds. Whether the Supreme Soviet of Byelorussia listens to its deputies and its electorate will emerge later this month.

Igor Germenchuk/ Novosti, Moscow

\section{Call for more spending}

\section{Washington}

THE US National Research Council (NRC), the research arm of the national academies of science, medicine and engineering, is calling for an increase of $\$ 500$ million in federal spending on competitive grants for research into agriculture, food and the environment.

This ambitious proposal from the NRC's board of agriculture appeared almost on the eve of President George Bush's expected announcement of acrossthe-board cuts in federal spending in order to meet deficit reduction targets.

But instead of watering down its recommendations in the light of the current financial climate, the NRC report, published on 6 October, argues that a substantial investment in agricultural research will improve international competitiveness and help reduce the budget deficit. The increase should be made next year and should not come from the reallocation of existing research programmes, it says.

NRC complains that there has been "little, if any, real growth" in agricultural research spending since 1955. Last year, the US Department of Agriculture's (USDA's) total research spending was only 4.6 per cent of the total federal research budget. While problems in agriculture increase, the report says, opportunities are missed: the slow application of biotechnology to agriculture is cited as a notable problem.

NRC proposes that a new independent office be set up within USDA's office of science and education to administer new grants, and that six programme areas should be established: plant systems; animal systems; nutrition, food quality and health; natural resources and the environment; engineering, products and processes; and markets, trade and policy. At present USDA spends only $\$ 40$ million on competitive research grants, and in a narrower field of research.

NRC also recommends that USDA should increase the duration of grants from the present two years, as well as their size, which now averages only $\$ 50,000$ a year. By contrast, the average grant awarded by the National Institutes of Health is $\$ 155,000$.

The aim of the suggested programme would be to secure the proven high economic return on investment in agricultural research. Other objectives would be to attract the best talent from the entire research sector into agricultural research, to expand knowledge in all the disciplines underpinning agriculture as well as contributing to advances in other areas.

Officials in the Department of Agriculture support the proposal, but its fate will be not be known until the president submits his 1991 budget proposal to Congress.

Christine McGourty 